\title{
The Nature of Science: Case Study of University of Tehran Undergraduate Students' Attitude
}

S. Abdolmaleki, K. Dorrani (Ph. D),

N. Karamdoust (Ph. D), M. Sadrolashrafi (Ph. D)

Abstract: Achieving a scientific literacy is the purpose of teaching the science curriculum in educational svstems in the world. One of the most important and the most essential components that increases scientific literacy in students, is teaching about the nature of science. Purpose of this study is to investigate the attitude of undergraduate students at University of Tehran toward the nature of science as a component of scientific literacv. The research is descriptive and was conducted in survev studv method. The population of this research includes all undergraduate students in faculties of psychology and educational sciences. and basic sciences. From this population, a sample size of 779 persons in stratified sampling method and considering the proportions (gender and facultv) was selected. In order to collect the attitudes of students about the nature of science, a questionnaire was designed based on the theoretical foundations of the project 2061 and its reliability and validity were examined and approved. One-sample ttest results indicate that the average of understanding the nature of science and its dimensions in students have significant differences with the average scores. Also the MANOVA test shows that there are significant differences between factor levels of faculties (faculty of psvchology and educational sciences and faculty of basic sciences) about "nature of science" variable. Results showed that students have poor understanding about the nature of science and its dimensions. Based on the analysis of the results of conducted researches. the reasons can be traced in these factors: paving no attention to the components of nature of science in the development and design of science curriculum, low teachers' knowledge and understanding about nature of science. lack of the development of science and technology in society and lack of the economical, political and cultural support structures for science and its values. The results also showed that students of basic science have more understanding about nature of science than students of psychology and educational sciences. The reason for that can be found in the nature of academic disciplines in two faculties and the amount of addressing the subiect matters about science and nature of science in their curriculum.

Key Words: Scientific literacy, Nature of Science, The Scientific Worldview, Scientific Inquiry, The Scientific Enterprise, Project 2061 .

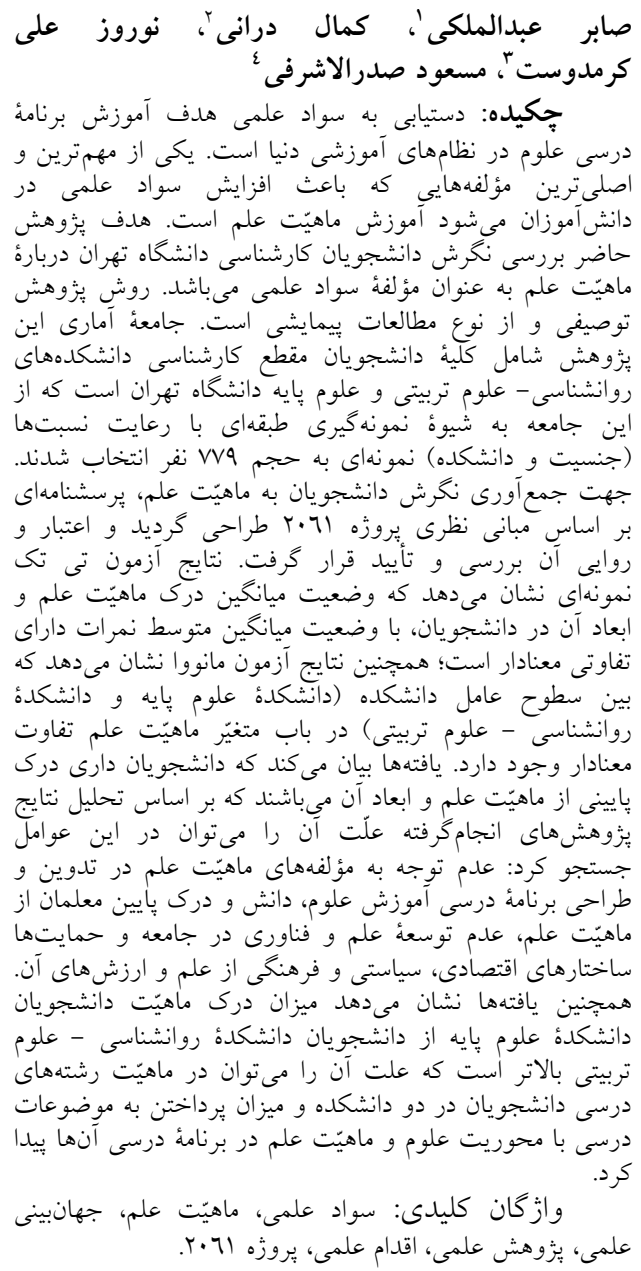

رايانامه: s.abdolmalaki@gmail.com 
امروزه در جامعله مدرن و فنّاورى محور، يرورش سواد علمسى ' عنصـرى اساسى و محسورى در

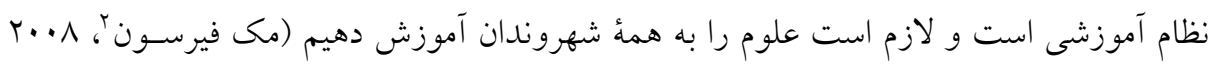

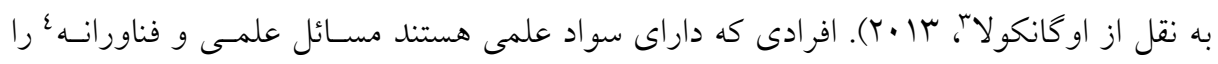

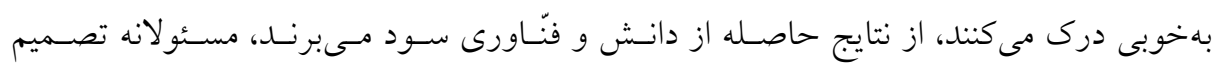

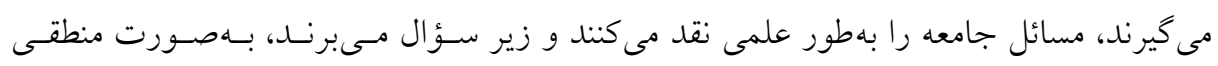

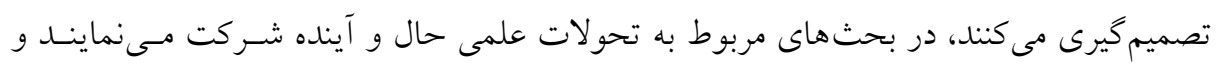

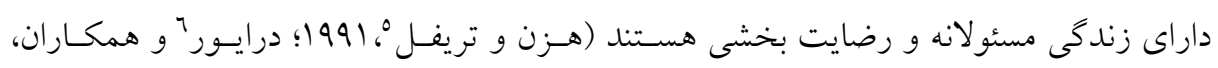

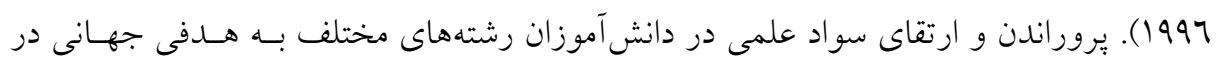

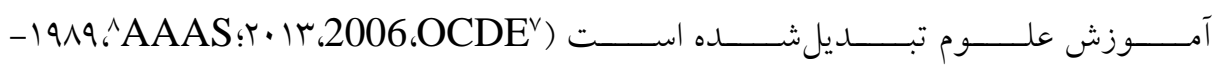

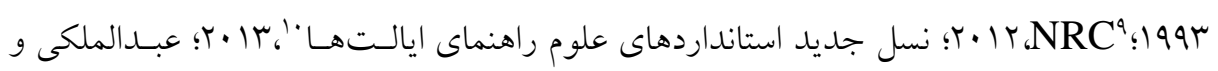

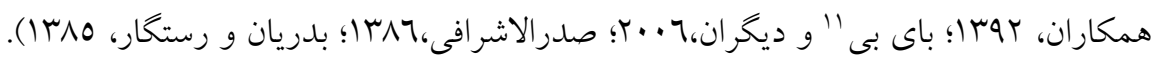

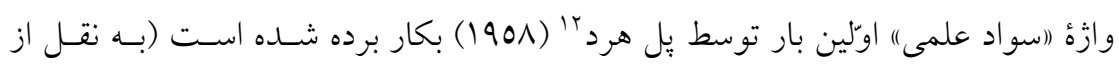

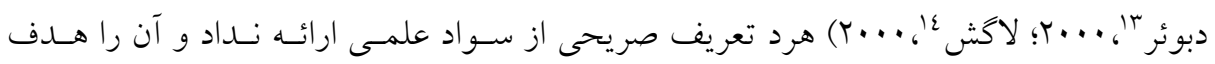

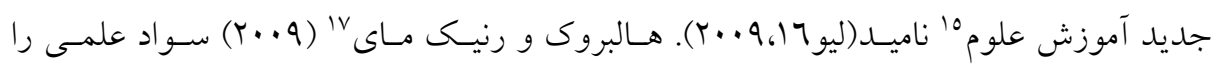

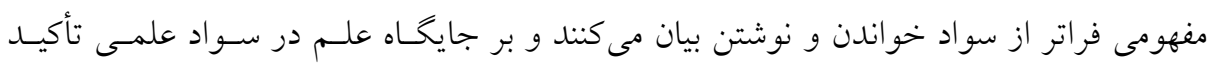

1.Scientific literacy

2. Mc Phearson, P.T

3 .Ogun kola

4. Scientific and technological

5 .Hazen, Trefil

6. Driver, R.

7. Organisation for Economic Co-operation and Development (OECD)

8. American Association for Advancement of Science

9. National Research Council

10. NGSS (Next Generation Science Standards) Lead States

11 .Rodger Bybee

12 .Hurd .P

13 .Debooer

14 .Laugsch, R.C

15 .Education Science

16 .Liu

17 .Holbrook \& Rannikmae 


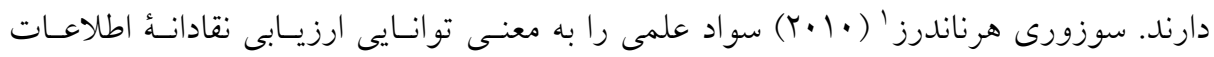

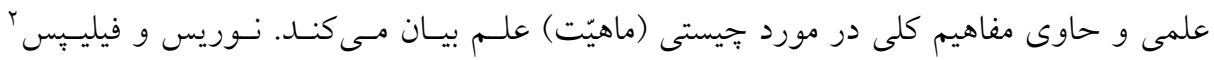

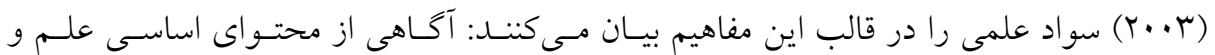

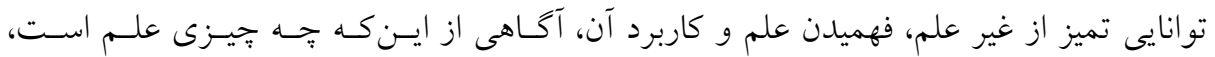

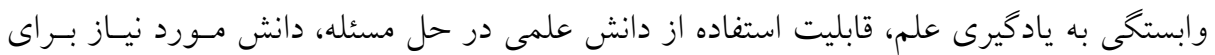

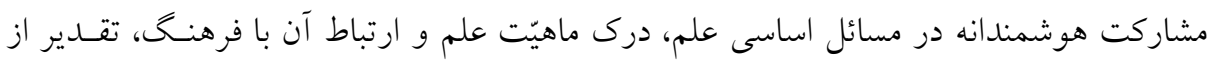

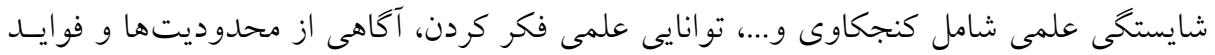
علمى، تو انايى تفكر انتقادى دربارهٔ علم.

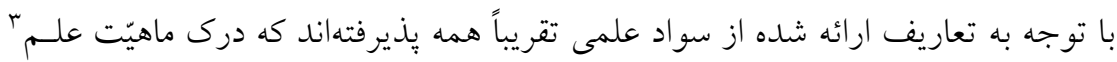

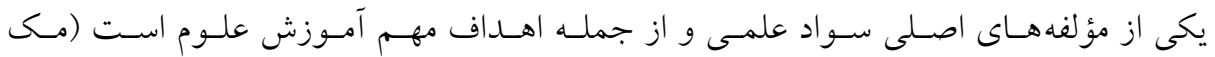

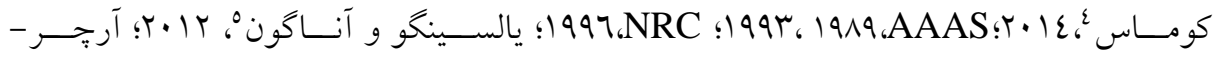

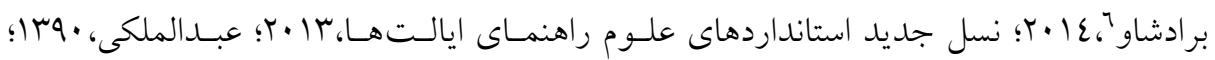

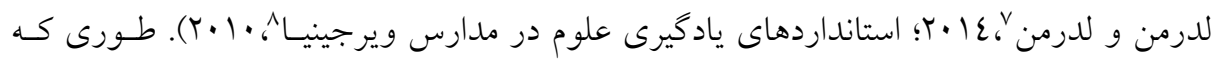

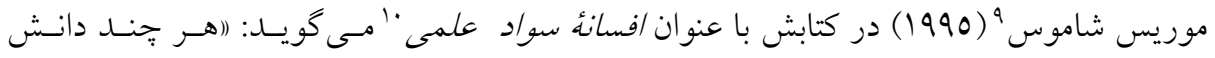

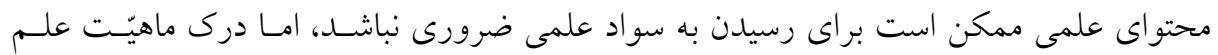

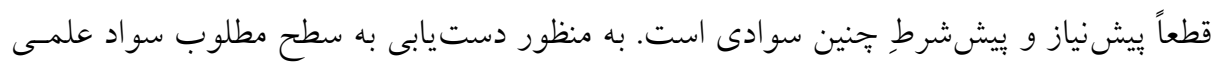

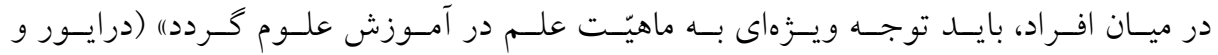
همكاران، (1997).

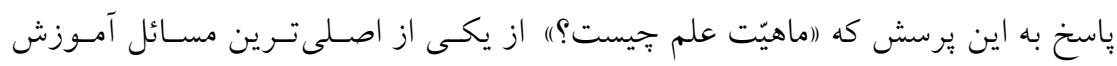

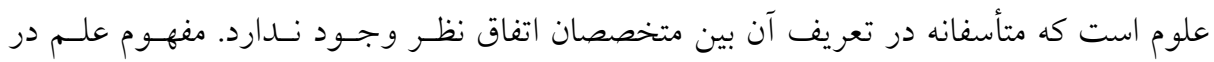

1. Suzuri-Hernandez

2. Norris, S.P., \& Phillips, L.M

3. Nature of Science

4. William F. McComas

5. Yalcinoglu ,P \& Anagun .S

6. Archer-Bradshaw

7 . Lederman, N. G. \& Lederman, J. S

8. Science Standards of Learning for Virginia Public Schools

9. Shamos, $M$

10 . The Myth of Scientific Literacy 
مسير تكامل خود، سيرى از تعاريف مختلفى داشته است. از تعاريف تجربه گرايان كه مبناى علـم را مشاهده و تجربه مى تانند تا تعاريف امروز كه عنصر انسانى نيـز بــه آن اضـافه شــده اسـت و

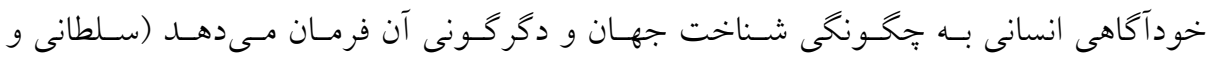

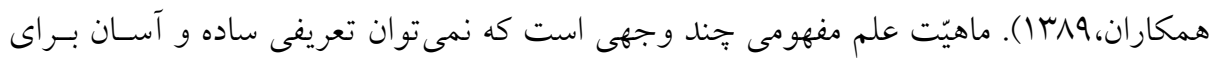
آن ارائه نمود. اين موضوع شامل جنبه هايى از تاريخ، جامعهشناسى و فلسـفه علـوم هسـت و در بسيارى از موارد به عنوان معرفتشناسى علوم، ويزّكى دانش علمسى و بـهـ عنـوان روشسى بــراى كسب آكاهى تعريف كرديده است.(بل 'و همكاران، +. (Y). ماهيّت علم به مقوله معرفتشناسىى علم مى يردازد و دانش را به عنوان روشى براى كسب آكاهى يا مجموعهاى از ارزشها و باورهـا كه از رشد و توسعه دانش علمى جدايىنايذير مىباشند قلمداد مى كند (لدرمن'، r99 او 1999). باوجود بيشرفتهاى جشمخير در امر توصيف دانش، هيت گونه تعريف واحدى از (ماهيّت علـم)"

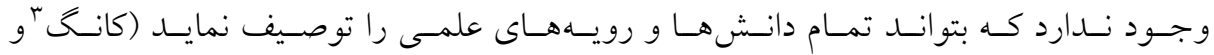

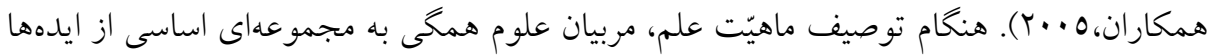
رجوع مى كنند كه به عنوان عملىترين ايدهها در محيط مدارس و كارآمدترين مفـاهيم در ايجـاد سواد علمى تلقى مى گردند اين ايدهها و مفاهيم عبارتانــد از مـوقتى بـودن؛، شـواهد تجربسى؛

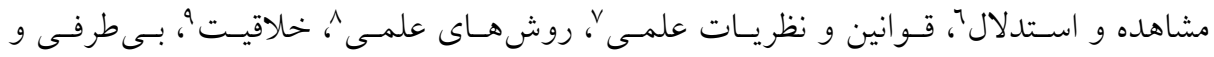

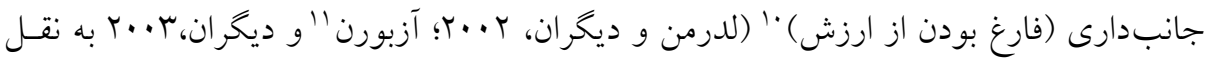

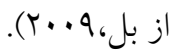

1. Bell, R.L

2 . Lederman, N. G

3 . Kang,S

4. Tentativeness

5. Empirical evidence

6. Observation and inference

7. Scientific laws and theories

8. Scientific methods

9. Creativity

10. Objectivity and subjectivity

11 . Osborne, J 


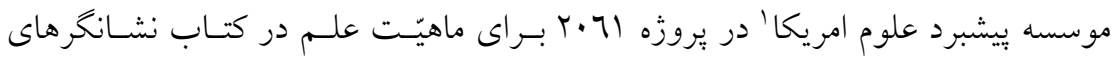

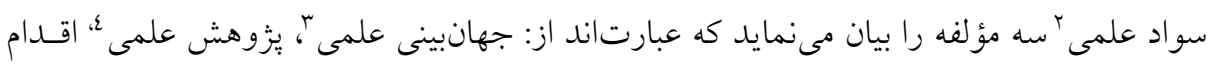
علمى (1994،AAAS) (19).

\section{جهانبينى علمى}

مفهوم جهانبينى بر تصورات افراد از نقـشهايشـان در جهـان، رابطـهُ بشـر بـا محسيط و

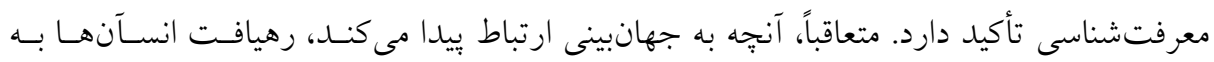

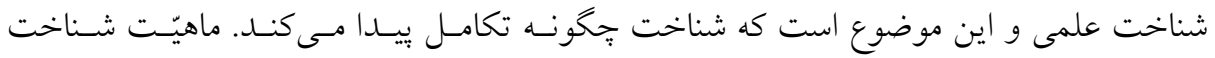

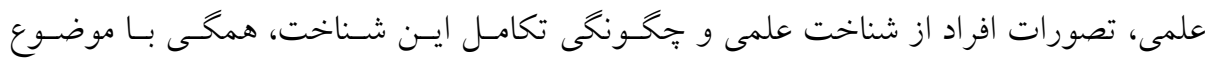

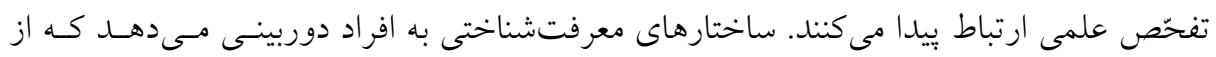

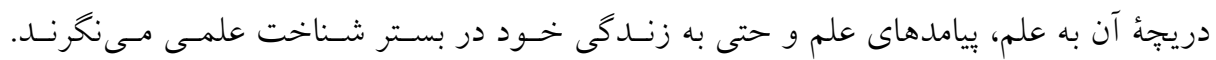

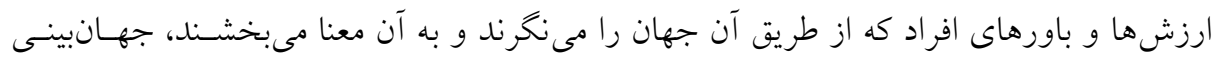

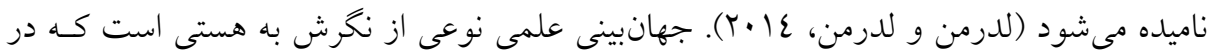

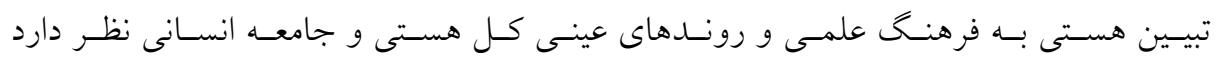

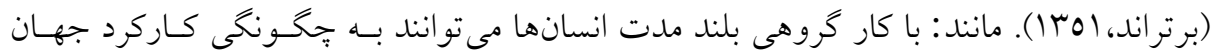

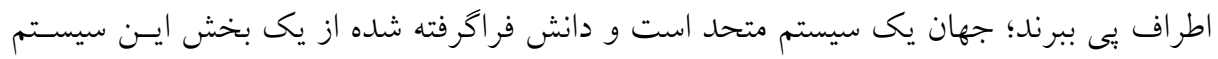

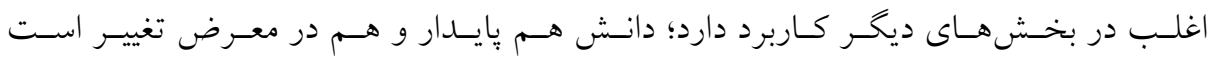

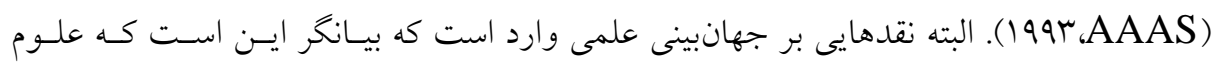

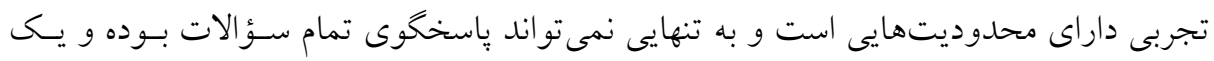

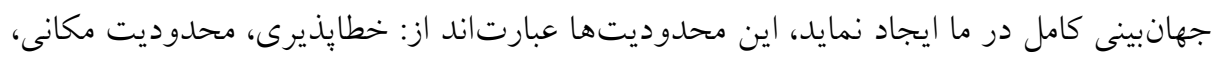

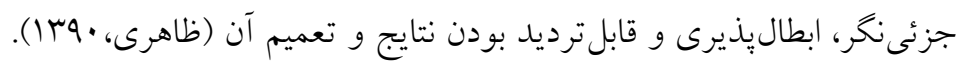

1. American Association for Advancement of Science

2 . Benchmarks for science literacy

3 .The Scientific Worldview

4. Scientific Inquiry

5. The Scientific Enterprise 


\section{ئزوهش علمى}

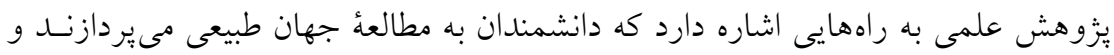

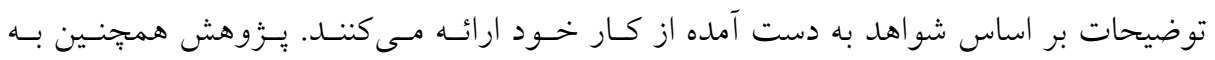

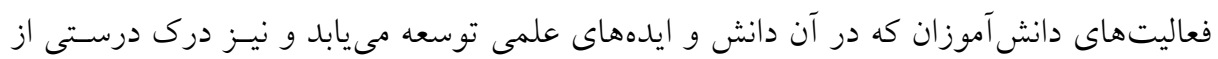
نحوهُ مطالعهُ جهان طبيعى به دست مى آورند، كفته مى شود (Y....NRC).

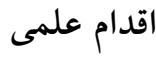

اقدام علمى ابعاد شخصى، اجتماعى و سازمانى دارد. فعاليتهاى علمى متمايزكنندهُ دوران

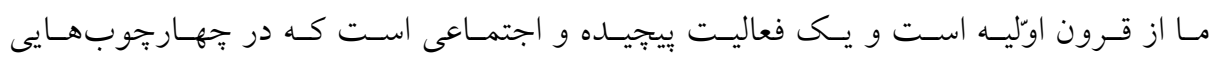

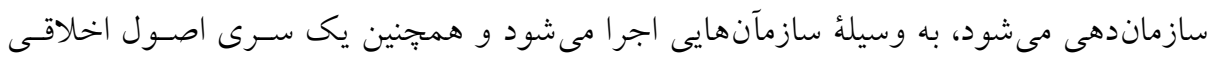

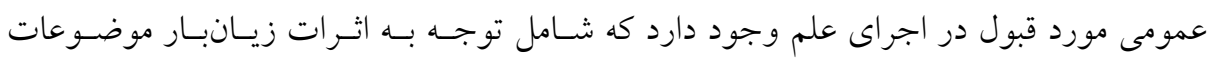

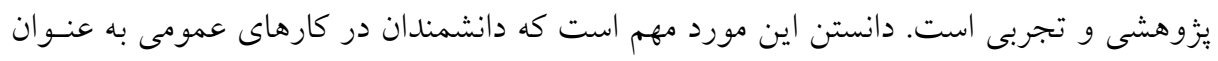

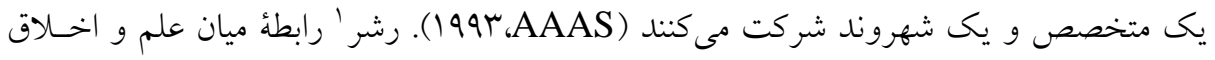

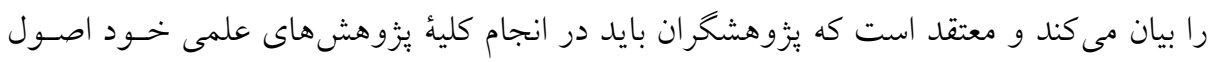

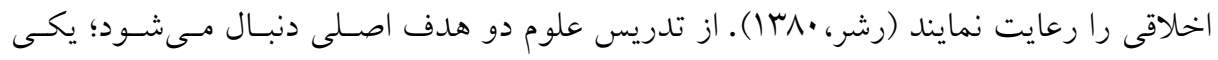

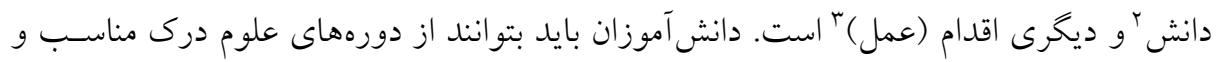

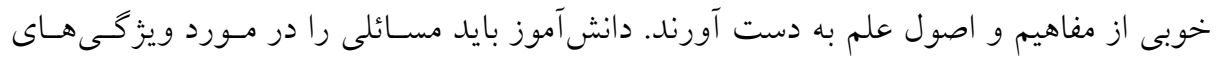

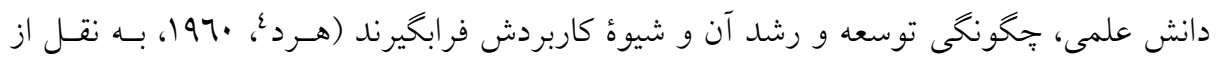

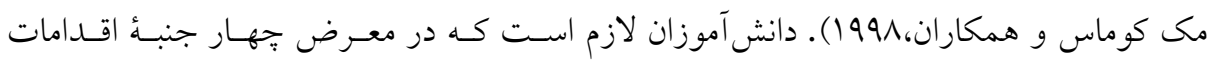

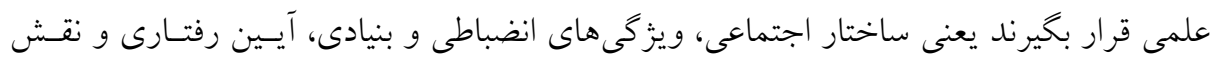

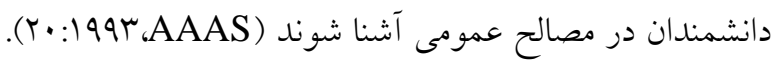

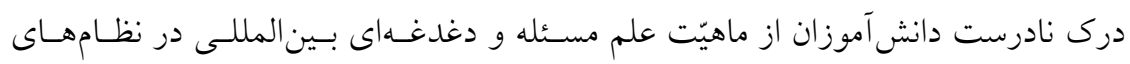

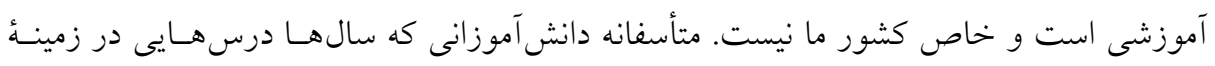

1. Resher

2. Knowledge

3. Enterprise

4. Hurd, P.DeH 
آموزش رسمى علوم داشتهاند هنوز نمى تو انند درك درست و دقيقى از ماهيّت علوم داشته باشند

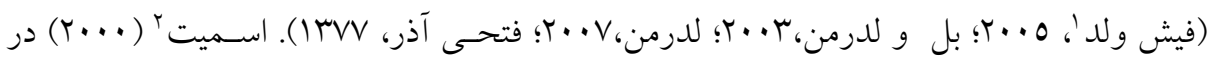

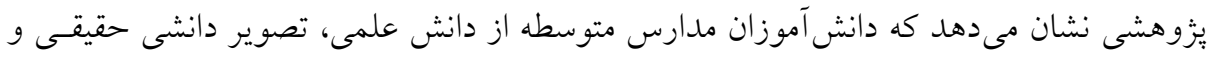

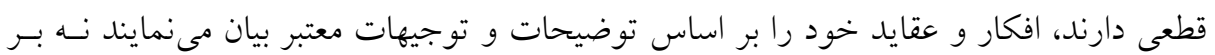

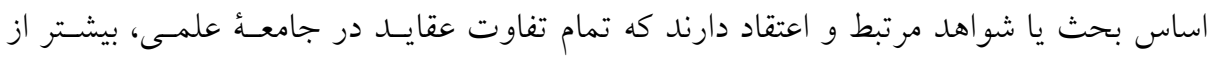

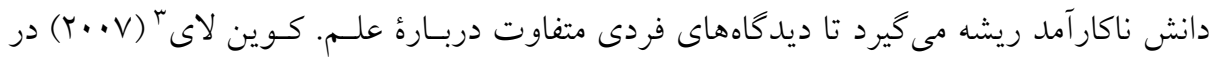

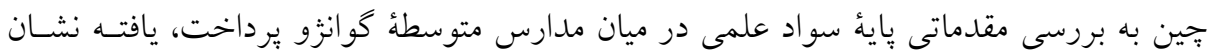

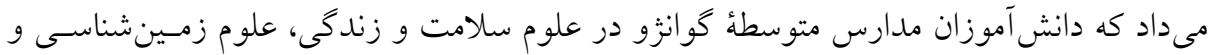
علوم فضا بهتر بودند و در ماهيّت علم و علوم فيزيكى ضعيف بودند. او همتهنسين نشـان داد بسين دانش آموزان در سطوح بالا و سطوح بايين از لحاظ سو اد علمسى تفـاوت معنـادارى وجــود دارد.

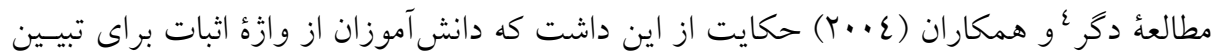

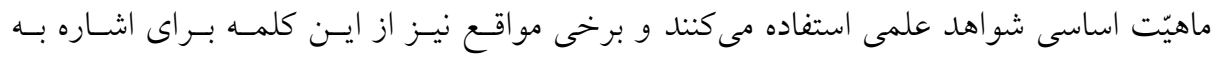

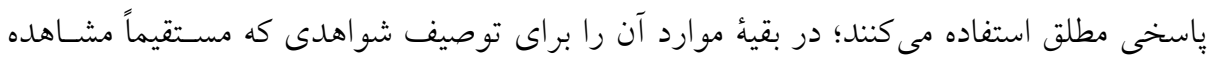

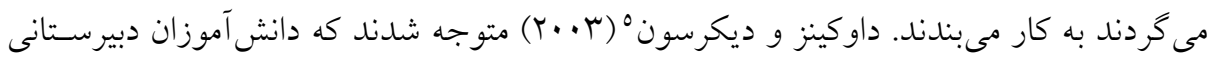

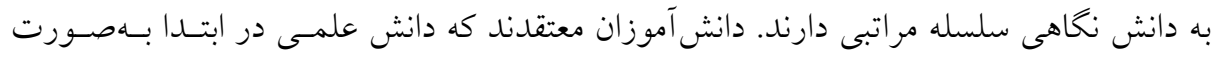

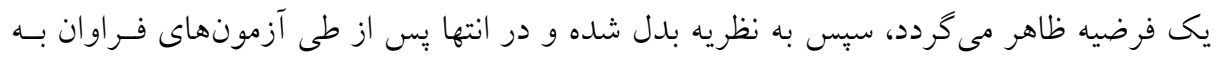

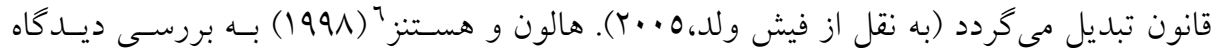

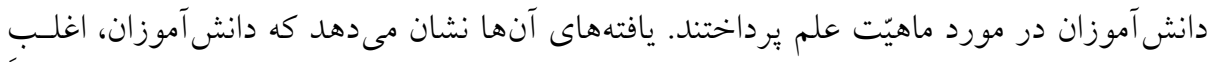
دانشمندان را به عنوان افرادى بىطرف در نظر مى گيرند كه از هيج گونه خلاقيتسى در كارهايشـان

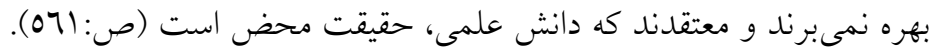

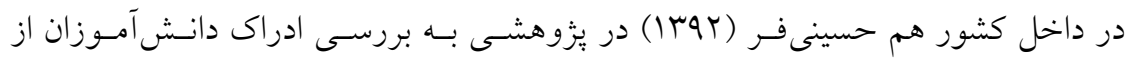

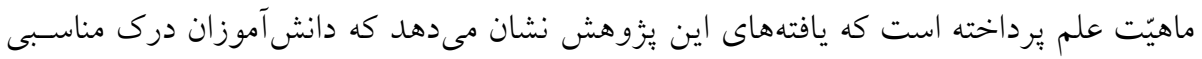

1. Fishwild

2. Smith, C.L

3. Xiao Qin LAI

4. Dagher

5 . Dawkins, K.R., \& Dickerson, D.L

6 . Halloun, I., \& Hestenes, D 
از ماهيّت علم ندارند، همجهنين بين درك دانش آمـوزان از ماهيّـت علـم در مــدارس بــا رويكـــد صرفاً علمى و مدارس با رويكرد علمى و مذهبى تفاوت معنادارى وجود ندارد. سعيدى (•وبا) در يزّوهشى به بررسى ديد گَاه هاى دانش آموزان و معلمان علوم دوره راهنمايى از علم و ماهيّـت آن يرداخت كه نتايج اين بررسى نشان داد كه دانش آموزان درك درستى از ماهيّت علم نداشتند، همجنين درك درستى از مطالب موجود در كتابهاى درسى علوم نيز نداشتند.

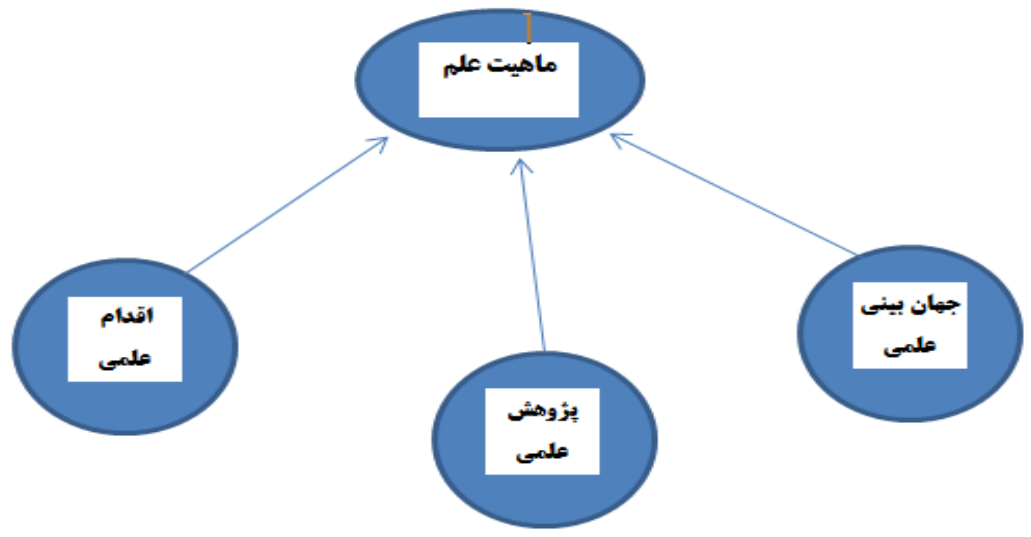

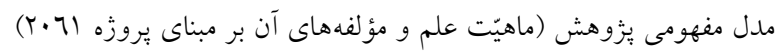

بنا بر مطالب بيان شده هدف جهانى آموزش علوم دستيابى به سواد علمى است. يكى از مؤلفههاى اصلى ايجاد سواد علمى در دانشآموزان، آموزش ماهيّت علم است. از اين رو با توجه به جايخاه و نقش ماهيّت علم در دستيابى به سواد علمى، در يزّوهش حاضر به بررسى وضعيت ماهيّت علم و ابعاد آن در دانشجويان برداختهشده است. در جهت تحقق اين اهداف سؤالات زير مطرح گرديله است:

- وضعيت ماهيّت علم و ابعاد آن در دانشجويان (دانشكدهُ روانشناسى - علوم تربيتى،

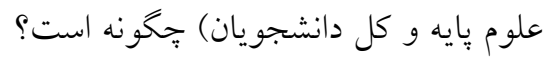

- وضعيت ماهيّت علم با توجه به متغيّرهاى جنسيت و دانشكده در دانشجويان

(دانشكده روانشناسى - علوم تربيتى و علوم يايه دانشخاه تهران) جِّونه است؟ 


\section{روش}

روش بئوهش، جامعه، نمونه گيرى، ابزار بُزوهش روش

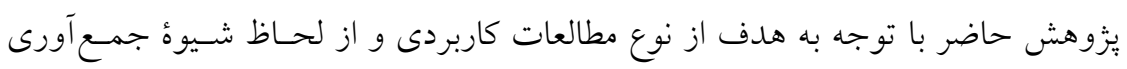

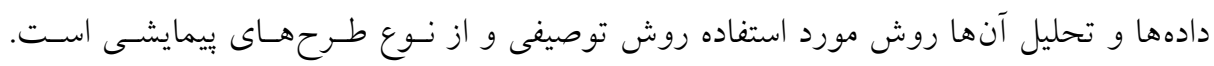

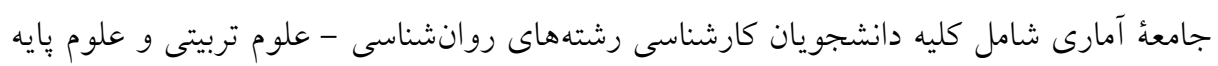

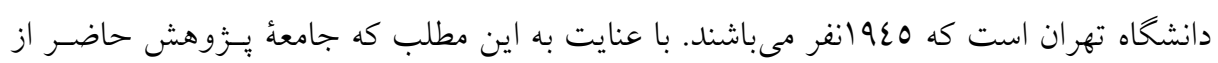

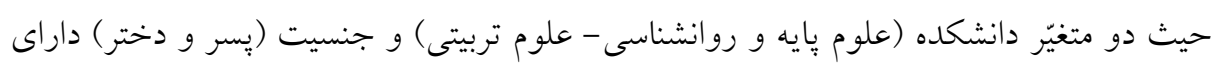

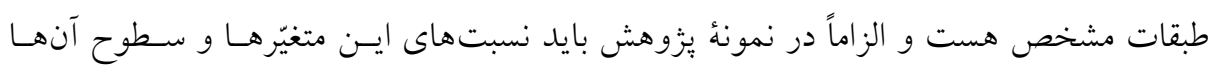

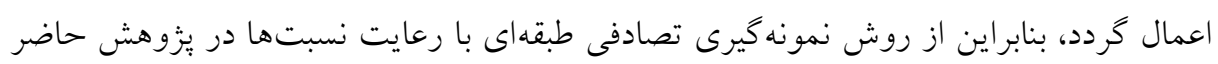

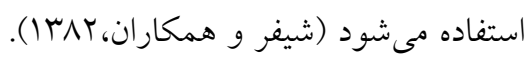

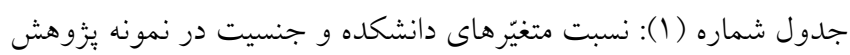

\begin{tabular}{|c|c|c|c|c|c|c|c|}
\hline \multirow{2}{*}{ حمجنم } & \multicolumn{2}{|c|}{ تعداد در نمونه } & \multicolumn{2}{|c|}{ نسبت جنسيت } & \multirow{2}{*}{ جامعبه به } & \multirow[t]{2}{*}{ تعداد } & \multirow[t]{2}{*}{ دانشكلده } \\
\hline & دختر & بـس & دختر & ְֶ, & & & \\
\hline וTד & $\varepsilon \varepsilon r$ & 119 & $\%$. & $\%$. & $\%$ & $10 \wedge r$ & علوم بايه \\
\hline l々A & 1.0 & $\varepsilon r$ & $\% \mathrm{VI}$ & $\%$ rq & $\% 19$ & rat & علوم تربيتى \\
\hline VVq & $0 \leqslant V$ & rrt & $\% \cdot 0$ & $\% . r 90$ & $\% 1 \cdots$ & 1920 & كل \\
\hline
\end{tabular}

در يزوهش حاضر براى طراحى ابزار بزوهش مراحلى به اين شرح راطى كرديم: ابتـدا

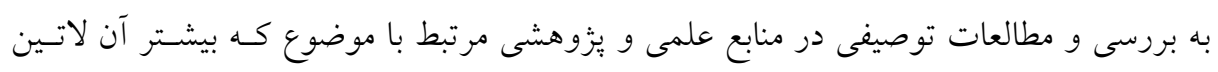

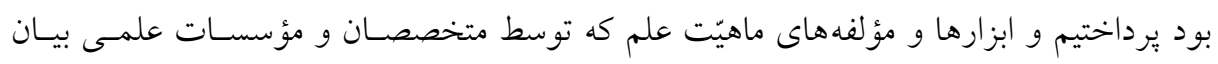

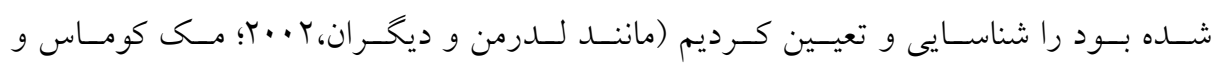

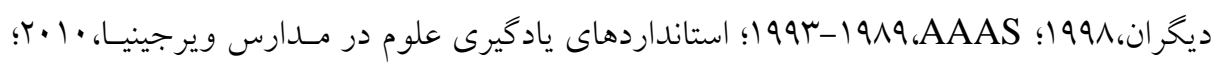

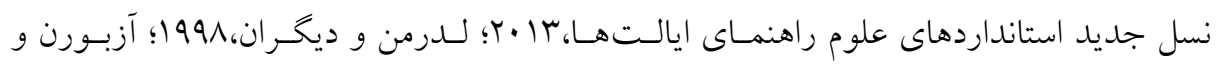
همكاران، ب. (Y). در مرحله بعدى زير نظر متخصصان، اساتيد مشاور و راهنما از بين اين ابزارهـا 
و مؤلفههاى بيانشده، مؤلفههاى ماهيّت علـم، كـهـ بـهـ وسـيلةُ انجمـن بيشـبرد علـوم در امريكـا

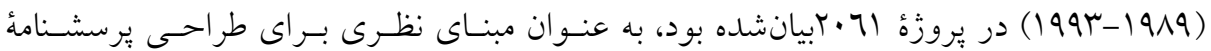

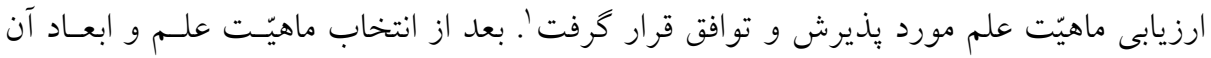

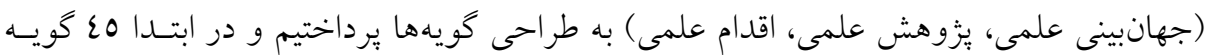
طراحى شد كه بعد از ارزيابى كويه ها توسط متخصصان (روايسى محتـوايى و صـورى) و و انجـام

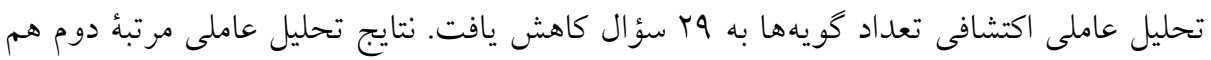

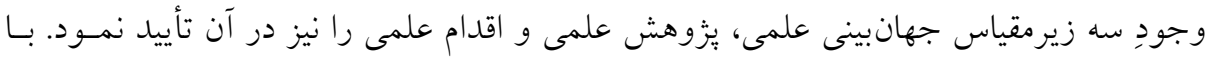

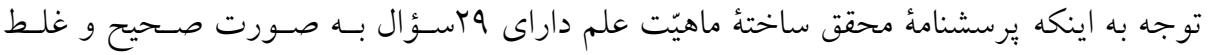

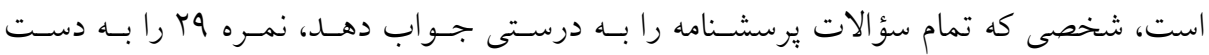

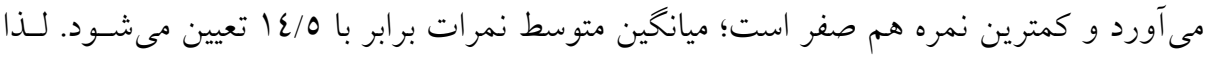

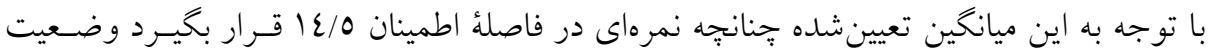

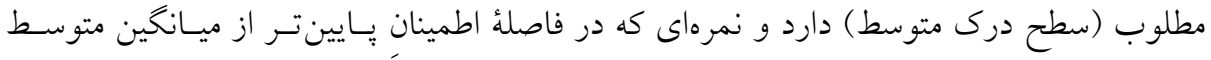
نمرات قرار گيرد وضعيت نامطلوبى (سطح درك يايين) دارد و نمرهاى كـه در بـالاتر از ميـانخين

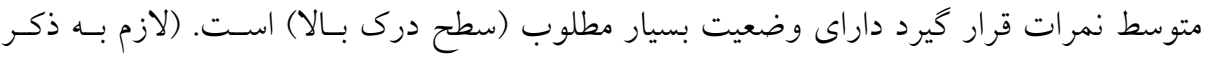

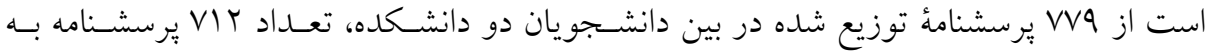

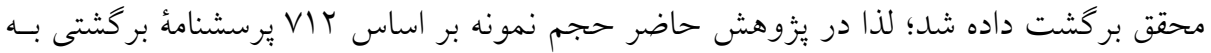

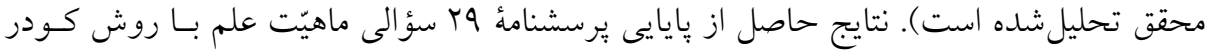

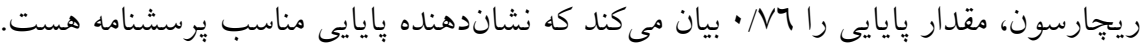
جدول شماره (Y): برزسى بايايى ابزار يزوهش

\begin{tabular}{|c|c|}
\hline كودر ريجاردسون & متغيّر \\
\hline$\%$ \% & ماهيّت علم \\
\hline$\%$ /Ar & جهانبينى علمى \\
\hline$\% / \wedge 9$ & يزوهش علمى \\
\hline$\%$ \% & اقدام علمى \\
\hline
\end{tabular}

'. علت انتخاب مؤلفههاى ماهيت علم در يروزه اج ·r به خاطر جامعيت، عمق و كاربردى بودن اين مؤلفهها بهعنوان ييشنهادى براى بهكارگيرى در برنامه درسى آموزش علوم است. 
روايى يرسشنامه از دو بعدِ روايى محتوا و تحليل عاملى تأييدى مورد بررسى قرار گرفت.

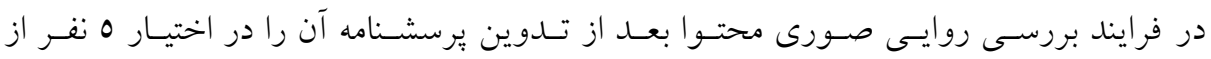

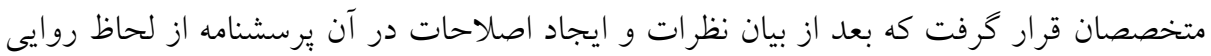

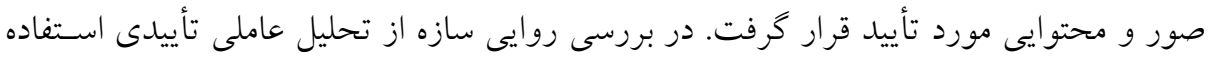

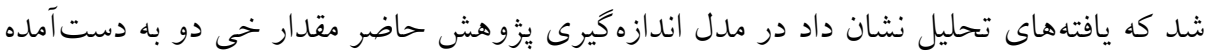

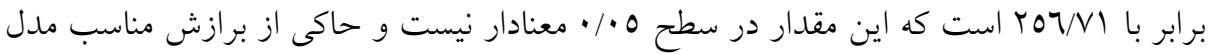

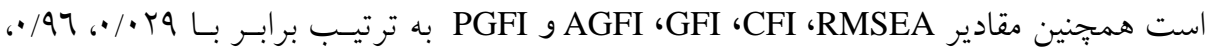

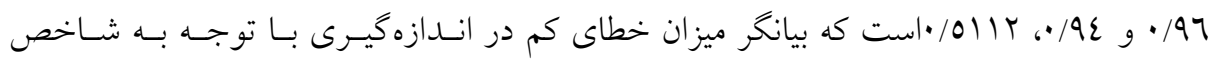

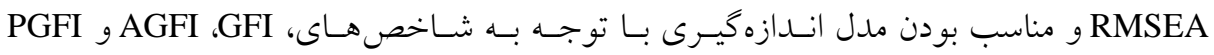
مطلوب و مناسب قلمداد مىشود.

\section{يافتهاى توصيفى بُزوهش}

جدول شماره (Y): وضعيت توصيفى متغيّر ماهيّت علم و ابعاد آن در كل دانشجويان

\begin{tabular}{|c|c|c|c|c|c|c|}
\hline ميانخين & استاندارد & ميانكين & ميانكين & فراوانى & | متغيَر & نوع \\
\hline.$/ 1 M M O$ & $r / 10.9$ & $-1 /$ TraY & $\mid r / r 7 \cdot 1$ & 011 & علمانبينى & دختر \\
\hline - rorl & $r / V r \cdot q$ & $-1 / \Upsilon \wedge T M$ & Ir/YIYY & 011 & علزوهش & \\
\hline - rorv & $r / \cdot \varepsilon \varepsilon \wedge$ & -1/90rY & $1 Y / 0 \varepsilon 71$ & 011 & اقدام علمى & \\
\hline . / ITr & $r / v 7 \cdot 1$ & $-1 / \Sigma q 4 \mid$ & $15 / \cdot 79$ & 011 & ماهيّت علم & \\
\hline.$/ .00$ & $r / 77 \cdot V$ & $-1 / 1 / 7.1$ & Ir/Vrqq & $r .1$ & جلمانبينى & بـسر \\
\hline$\cdot / / O V A$ & $r / A \cdot 1$ & $-Y / O r \cdot \varepsilon$ & $11 / 9 \vee 97$ & $r \cdot 1$ & عزُوهش & \\
\hline$\cdot / \cdot r \cdot r$ & r/VYVY & $-r / I V R T$ & II/rYVV & $r+1$ & اقدام علمى & \\
\hline$\cdot / \varepsilon \cdot r \mid$ & $r / V V I r$ & $-r / \varepsilon \wedge \varepsilon r$ & $1 Y / \cdot 10 \mathrm{~V}$ & $r \cdot 1$ & ماهيّت علم & \\
\hline$\cdot / / \vee \wedge \uparrow$ & $r / 07 V r$ & $-1 / 29970$ & $1 r / \cdots r o$ & VIr & |جلمانبيى & كل \\
\hline
\end{tabular}




\begin{tabular}{|c|c|c|c|c|c|c|}
\hline خانان & انحراف اندان إن & ميانخين & ميانخين & فراوانى & متغيّر & نوع \\
\hline 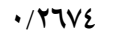 & r/.rrr & $-1 / 9 \cdot r 7$ & $1 Y / 097 \varepsilon$ & VIr & يُزوهش & \\
\hline$\cdot / \varepsilon \mid r \mu$ & $r / 0 \wedge 9$ & - & IY/rרזr & VIr & اقدام علمى & \\
\hline$\cdot / 41 \cdot 1$ & $r / .011$ & $-1 / 9 \wedge 9 \varepsilon$ & $1 Y / 0109$ & VIr & ماهيّت علم & \\
\hline . YVVAr & r/lros & $-Y / \cdot V Y V$ & $I r / \varepsilon r V r$ & $1 \varepsilon \wedge$ & على جلى & \multirow[t]{4}{*}{ علوم تربيتى } \\
\hline •/rعol & r/QAVI & $-Y / \varepsilon \varepsilon \mid \varepsilon$ & $1 Y / \cdot 0 \wedge 7$ & $\mid \varepsilon \wedge$ & & \\
\hline ./ OOVA & $r / \neg V \mu \varepsilon$ & $-r / A r \varepsilon O$ & $11 / 7700$ & $1 \varepsilon \wedge$ & اقدام علمى & \\
\hline . / $r r V$ & $\varepsilon /$ IroV & $-Y / \varepsilon \varepsilon 97$ & $1 Y / \cdot 0 \cdot \varepsilon$ & $\mid \varepsilon \wedge$ & ماهيّت علم & \\
\hline • rvvo & $r / \neg \varepsilon Y I$ & $-\bullet / \Lambda Y \varepsilon I$ & Ir/7voq & $07 \varepsilon$ & علمى جانبينى & \multirow[t]{4}{*}{ علوم يايه } \\
\hline$\cdot / \varepsilon 107$ & r/VWIq & $-1 / 1 V r$ & Ir/rrV. & $07 \varepsilon$ & علمى عشى & \\
\hline - / lorr & r/TEYr & $-Y / 0010$ & $11 / 9 \varepsilon 10$ & $07 \varepsilon$ & اقدام علمى & \\
\hline - /乏IrA & r/rreA & $-1 / 0110$ & $\mid r / 9 \wedge 10$ & $07 \varepsilon$ & ماهيّت علم & \\
\hline
\end{tabular}

نتايج جدول نشان مى دهد وضعيت ميانخين دختران در متغيّر ماهيّت علم و سه زير عامـلِ

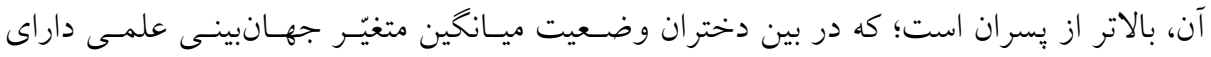

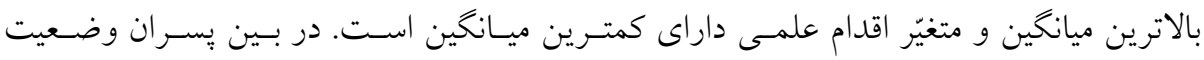

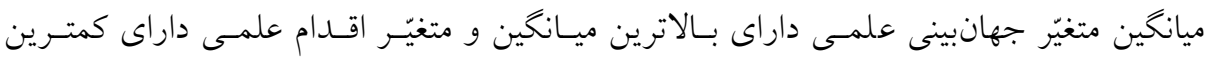

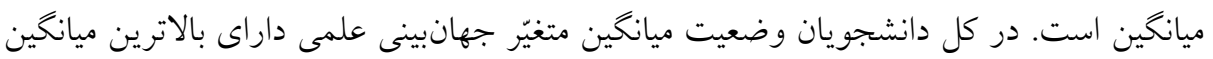

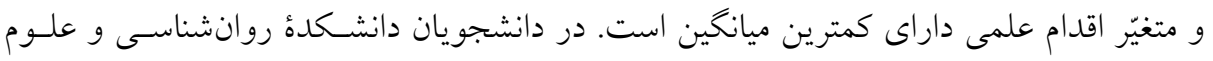

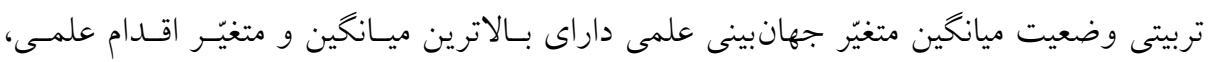

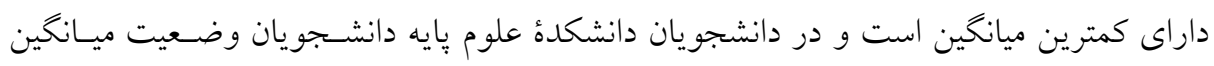

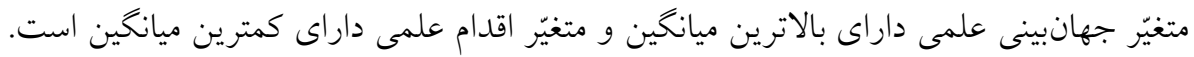




\section{يافتهاى مبتنى بر سؤالات يزّوهش}

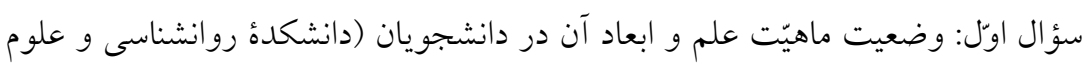

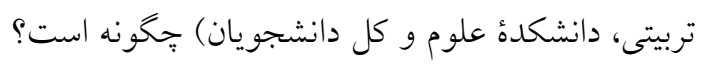

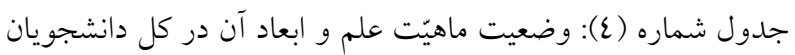

\begin{tabular}{|c|c|c|c|c|c|}
\hline Sig. & Df & $\mathrm{T}$ & | فراوانى & | متغيَر & نوع \\
\hline$\cdot \cdots$ & 01. & $-V / V \cdots$ & 011 & جهانبينى علمى & \multirow[t]{4}{*}{ دختر } \\
\hline$\cdot / \cdots$ & 01. & $-1 \varepsilon / 190$ & 011 & | يززوهش علمى & \\
\hline$\cdot \cdots$ & 01. & $-10 / 9 r 9$ & 011 & |قدام علمى & \\
\hline$\cdot \cdots$ & 01. & $-|V / 7| \mid$ & 011 & ماهيّت علم & \\
\hline$\cdot \cdots$ & $r \cdots$ & $-I V / \cdot T_{0}$ & $r \cdot 1$ & جهانبينى علمى & \multirow[t]{4}{*}{ 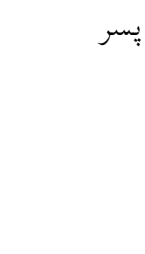 } \\
\hline$\cdot \cdots$ & $r \cdots$ & $-1 r / 01 T$ & $r \cdot 1$ & | يززوهش علمى & \\
\hline$\cdot \cdots$ & $r \cdots$ & $-r \cdot / 7 \cdot 9$ & $r \cdot 1$ & |قدام علمى & \\
\hline$\cdot / \cdots$ & $r \cdots$ & $-1 T / 1 Y \varepsilon$ & $r \cdot 1$ & ماهيّت علم & \\
\hline$\cdot / \cdots$ & V11 & $-9 / 10 \varepsilon$ & VIT & جهانبينى علمى & \multirow[t]{4}{*}{ كل } \\
\hline$\cdot \cdots \cdot$ & V11 & $-1 \cdot 1071 \mathrm{r}$ & VIr & يززوهش علمى & \\
\hline$\cdot \cdots$ & V11 & $-1 \varepsilon / 19 \wedge \varepsilon$ & VIr & |قدام علمى & \\
\hline$\cdot / \cdots$ & VII & $-1 r / 01 T$ & VIr & ماهيّت علم & \\
\hline$\cdot \cdots$ & $1 \varepsilon V$ & $-10 /$ TVVT & $1 \varepsilon \wedge$ & جهانبينى علمى & \multirow[t]{4}{*}{ علوم يايه } \\
\hline$\cdot \cdots$ & $1 \varepsilon V$ & $-9 /$ TAVQ & 1乏^ & يززوهش علمى & \\
\hline$\cdot \cdots$ & $1 \varepsilon V$ & $-19 / 7 \varepsilon$ oV & $1 \varepsilon \Lambda$ & |قدام علمى & \\
\hline$\cdot / \cdots$ & $07 \pi$ & $-|V / \varepsilon| \Lambda$ & $07 \varepsilon$ & ماهيّت علم & \\
\hline$\cdot \cdots$ & $1 \varepsilon V$ & $-10 /$ TVVT & $1 \varepsilon \wedge$ & جهانبينى علمى & \multirow{4}{*}{ تروبيتى علوم } \\
\hline$\cdot \cdots$ & $1 \varepsilon V$ & $-9 /$ Y $\vee \vee$ & $1 \varepsilon \wedge$ & يززوهش علمى & \\
\hline$\cdot / \cdots$ & $1 \varepsilon V$ & $-19 / 7 \varepsilon$ OV & $1 \varepsilon \Lambda$ & |قدام علمى & \\
\hline$\cdot / \cdots$ & I乏V & $-1 \% / r 07$ & $1 \varepsilon \wedge$ & ماهيّت علم & \\
\hline
\end{tabular}


حاصل از تحليل آزمون T تكى نمونهاى نشان داد كه مقادير T حاصـل بـراى متغيّـر ماهيّـت

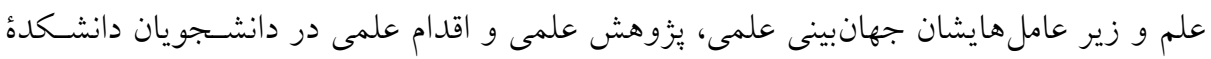

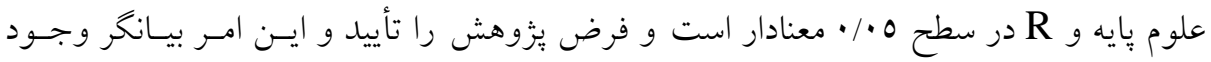

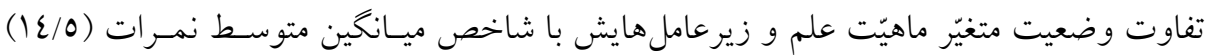

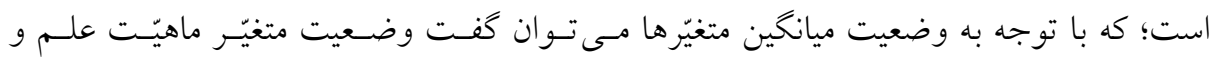
زيرعامل هايش در دانشجويان هيايينتر از وضعيت متوسط و در سطح نامطلوب قرار دارده

سؤال دوم: وضعيت ماهيّت علم با توجه به متغيّرهاى جنسيت و دانشكده در دانشجويان

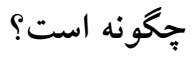
جدول شماره (0): آزمون مانووا جهت وضعيت ماهيّت علم با توجه به متغيّرهاى جنسيت و دانشكده

\begin{tabular}{|c|c|c|c|c|c|c|}
\hline Sig. & $\bar{F}$ & مجذورات مينين & آزادى & مجذورات & متغيَر & متغيَر \\
\hline$\cdot \cdots$ & $11 / 107$ & $7077 / 2 V \varepsilon$ & 1 & $7077 / 2 V \varepsilon$ & ماهيَت علم & دانشكده \\
\hline$\cdot \cdots$ & $v \cdot / \cdot r q$ & $0777 / 974$ & 1 & $0777 / 971$ & ماهيَت علم & جنسيت \\
\hline$\cdot / \cdot 1$ & ir/vor & $111 \mathrm{r} / \mathrm{VOT}$ & 1 & $111 \mathrm{r}$ Nor & ماهيَت علم & دانشكده · جنسيت \\
\hline & & $\lambda \cdot / 91 \mathrm{r}$ & $V \cdot \varepsilon$ & $\{77 \cdot 0 / \cdot 11$ & ماهيّت علم & خطا \\
\hline & & & VIT & $10 \cdot 9 \cdot \varepsilon V / I \sum V$ & ماهيَت علم & كل \\
\hline
\end{tabular}

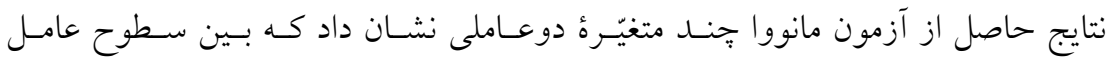
دانشكده (دانشكدة علوم يايه و دانشكدة روانشناسى - علوم تربيتى) در باب متغيّر ماهيّـت علـم

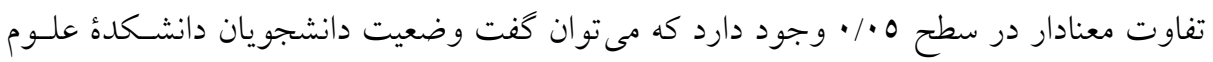
در اين متغيّر به مراتب بهتر و بالاتر از دانشجويان دانشكدهُ روانشناسى و علوم تربيتى است. بـين

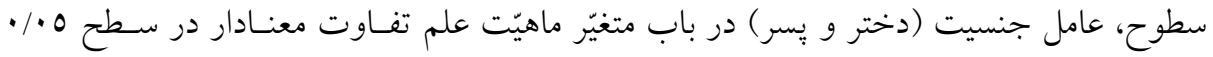
وجود دارد كه مى توان كفت وضعيت دانشجويان دختر در اين متغيّر به مراتـب بهتـر و بـالاتر از

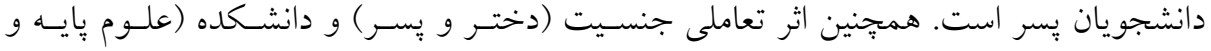

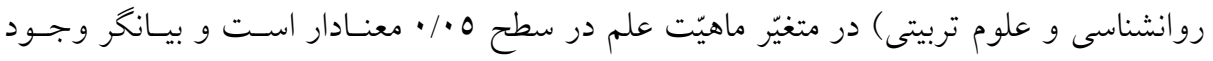

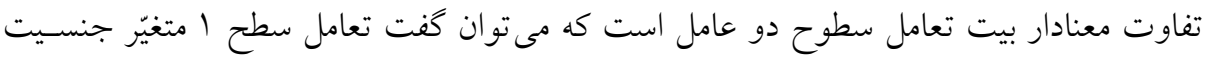


(دختر) با سطح ا دانشكده (علوم يايه) بالاترين وضعيت و تعامل سطح كامتغيّر جنسيت (يسـر)

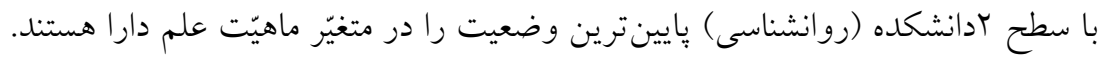

\section{بحث و نتيجه گيرى}

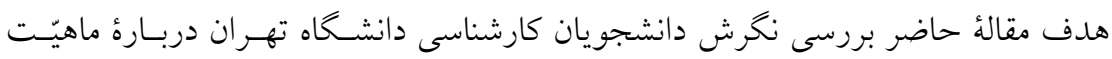

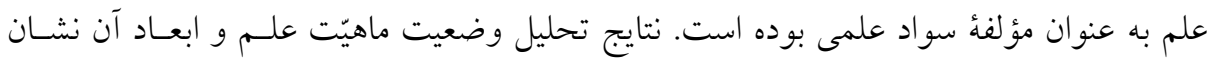

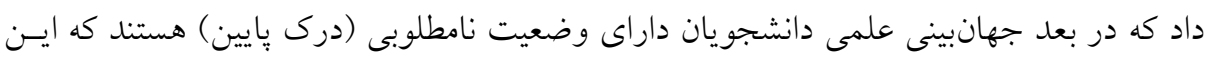

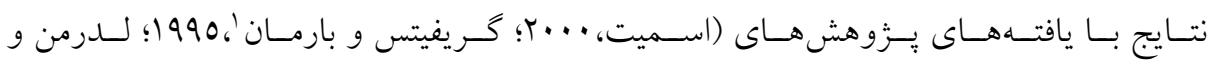

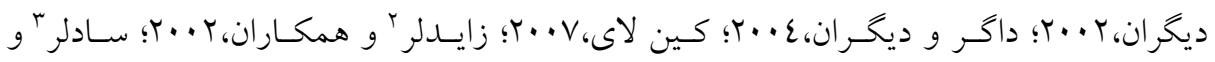

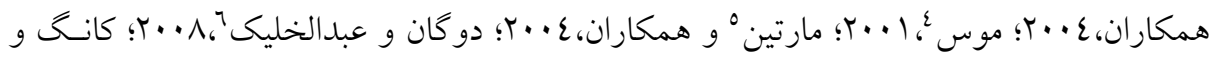

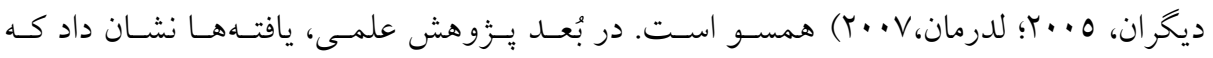

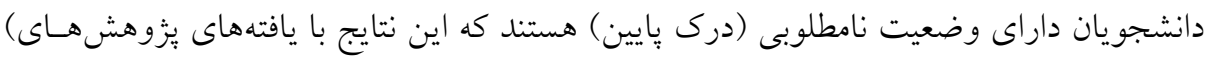

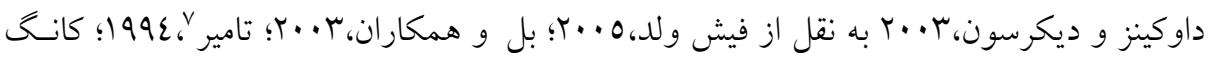

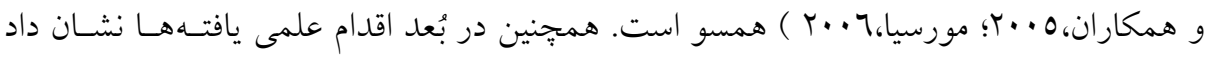

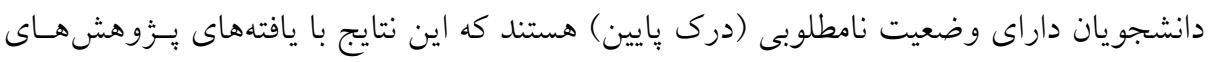

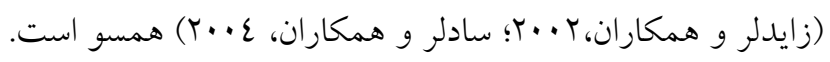

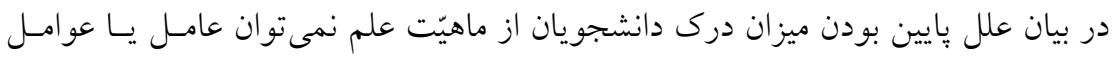

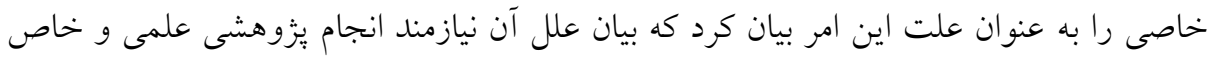

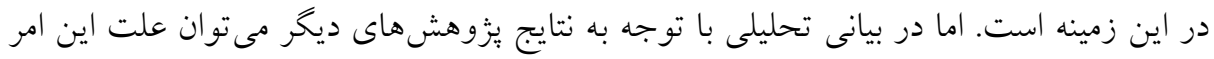

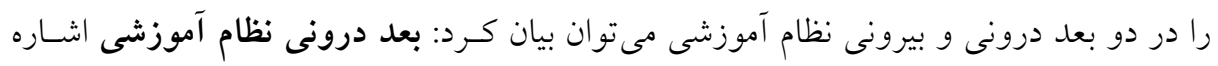

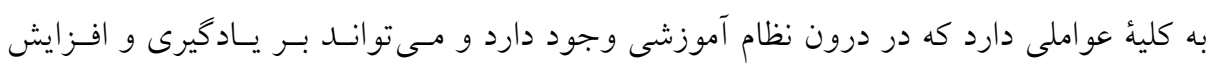

1 .Griffiths, A.K. \& Barman, C.R

2 .Zeidler, D.L

3. Sadler, T.D

4. Moss, D.M

5. Martin M.O

6. Dogan, N. \& Abd-El-Khalick, F

7. Tamir, $\mathrm{P}$ 
درى دانش آموزان از ماهيّت علم اثر كذار باشد؛ كه مهمترين آنها معلمان و برنامة درسى رسـمى

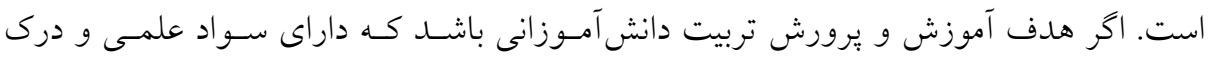

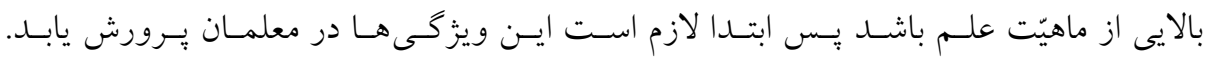

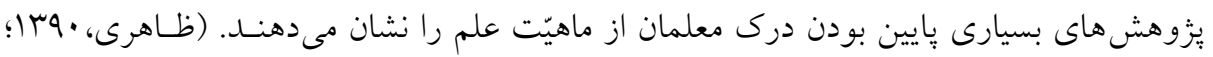

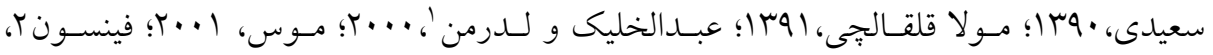

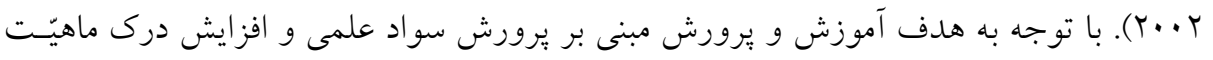

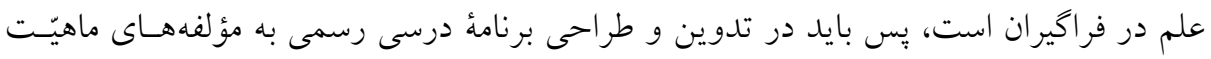

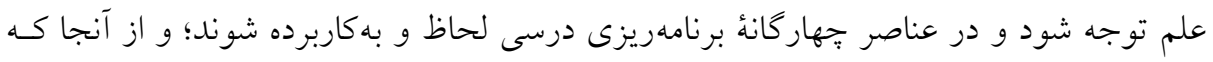

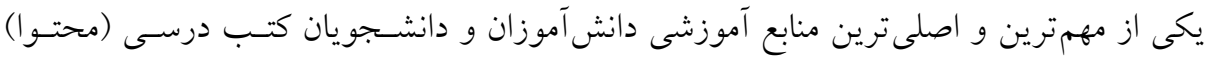

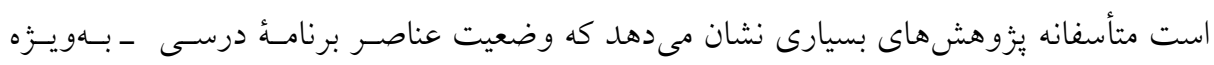

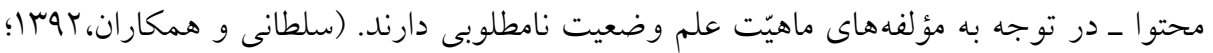

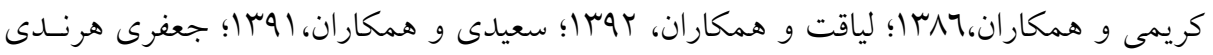

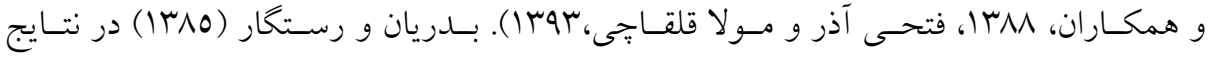
يُزوهش خود بيان مى كنند كه محتواى درسى علوم در ايران، هماهنخ با توسعهُ علـوم و فنـاورى

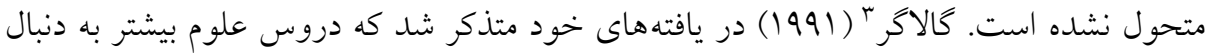
تأكيد بر بدنه و اصطلاحات دانش در علوم هستند تا اينكه به دنبال ماهيّت علم باشند.

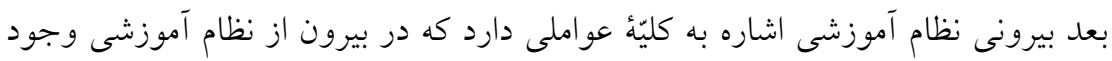

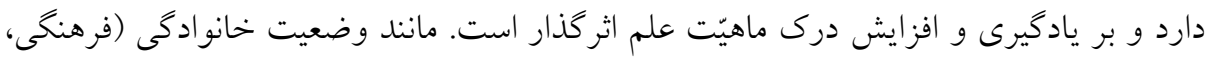

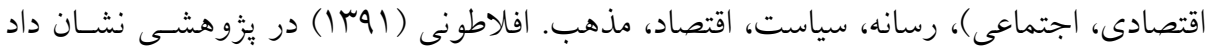

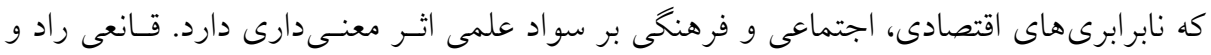

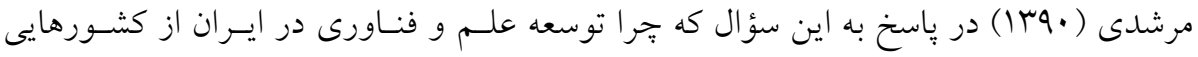

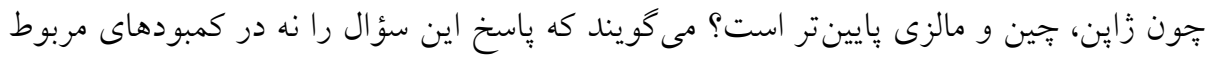

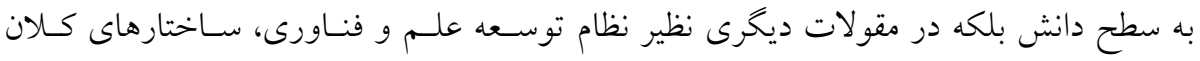
اقتصادى، متغيرهاى فرهنكى اجتماعى و غيره بايد جستجو كرد.

1. Abd-El-Khalick, F. \& Lederman, N. G

2. Finson, K. D

3. Gallagher,J.J 
قدمها و اقدامات اندكى درحركت به سمت دست يابى به اين اهداف آموزشى برداشـته شـده است، هرجند نخرانى هميشكى در مورد درك دانش آموزان از علـم وجــود دارد (لـدرمن، 1999)

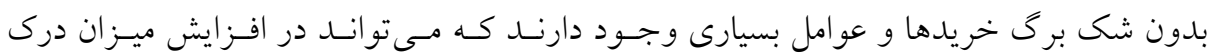
دانشآموزان از ماهيّت علم مؤثر باشد. ازجمله مىتوان عوامل به اين زير اشاره نمود: توجه به مؤلفههاى ماهيّت علم در تلدوين و طراحى برنامة درسى (در عناصـر اهــداف،

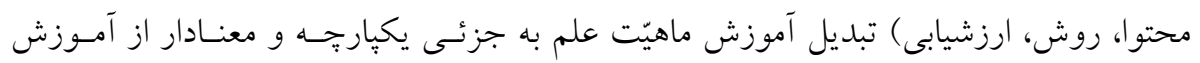
علوم است.

تأكيد بر فرهنگ علوم در مدارس (شاناهان و نيسواند ‘، (1) اشاره به جايخاه و نقشى كه نزاد، جنسيت، ارزش علم، فرهنگ علم، رفتار علمى، اخلاق علمى در مدرسه به عنوان يـى

$$
\text { اجتماع به وجود مى آورد. }
$$

افزايش دانش و درك معلمان علوم از ماهيّت علم و بررسىهاى علمى. توسهُ علم و فناورى در جامعه (اهميت جايخاه افزايش درى عام از علم)، حمايتها و ساختارهاى اقتصادى، تأكيد بر اهميت فرهنخ نخرش علمى سياستهاى جامعه.

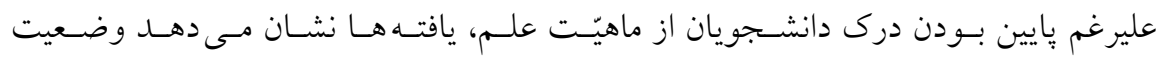
دانشجويان دانشكدهُ علوم در درك ماهيّت علم به مراتب بهتر و بـالاتر از دانشسجويان دانشـكده روانشناسى - علوم تربيتى است كه مى توان علت آن را در ماهيّت رشتههاى درسسى دانشسجويان در دو دانشكده و ميزان برداختن به موضوعات درسى با محوريت آموزش علوم و ماهيّـت علـم (در برنامه درسى آن) دانست. همجنين نشان مىدهد كه وضعيت دانشجويان دختر در درى علـم به مراتب بهتر و بالاتر از دانشجويان يسر است كه اين يافته بـا نتـايج يـزّوهش ظـاهرى ( •وسا) مغاير است. 
- بدريان، عابد و رستخار، طاهره (1^11). مطالعه تطبيقى استانداردهاى آموزش علوم دوره آموزش عمومى ايران و كشورهاى موفق در آزمون تيمز. ششمين همايش انجمن مطالعات برنامهُ درسى - فتحى آذر، اسكندر (ITVV) . بررسى درى ماهيّت علم در فراخيران، دبيران، دانشجويان و اساتيد علوم

$$
\text { آذربايجان شرقى. تبريز: يزوهشكاءة تعليم و تربيت اداره كل آموزش و يروشي. }
$$

- جعفرى هرندى، رضا؛ مير شاه ابر اهيمى، سيد ابراهيم و لياقتدار، محمدجواد (1MNA). بررسى تطبيقى عنصر هدف در برنامهُ درسى آموزش علوم ايران و جّند كشور جهان. مجلهُ علوم تربيتى دانشخاه شهيد

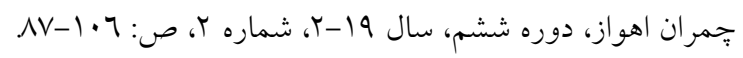

- راسل، برتراند (1) (1). جهانبينى علمى. ترجمه حسن منصور. تهران: انتشارات دانشخاه تهران.

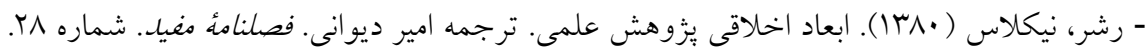

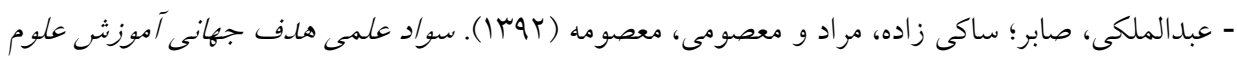
در قرن بيستويك با تأكيد بر /هلاف و محتواى برنامة درسى. همايش ملى تغيير برنامة درسى دورههاى تحصيلى آموزش و برورش عا, 10 اسفندماه - بيرجند - دانشخاه بيرجند.

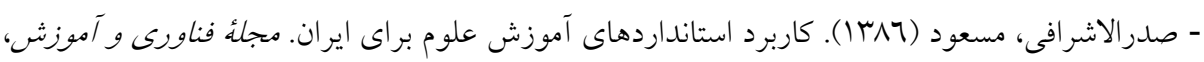
سال اوّل، جلد اوّل، شماره ع. - سعيدى، مريم ( •وسا). بررسى ديدكاههاى دانش آموزان و معلمان علوم راهنما ييى /ز علم و ماهيّت آن. پايانامهُ كارشناسى ارشد، دانشخاه تربيت دبيرى شهيد رجايى، دانشكدهُ علوم بايه.

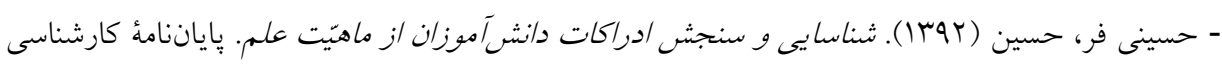
ارشد، دانشخاه تربيت دبيرى شهيد رجايى، دانشكدة علوم بايه.

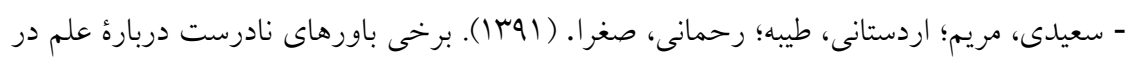
كتابهاى علوم دوره راهنماى. مجلئ بِّسى معلم فيزيكى .بيش شماره 1 ، تابستان.

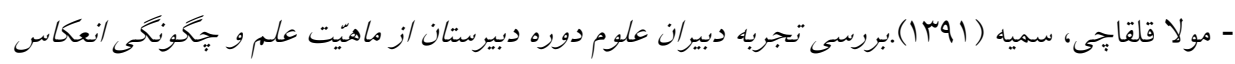

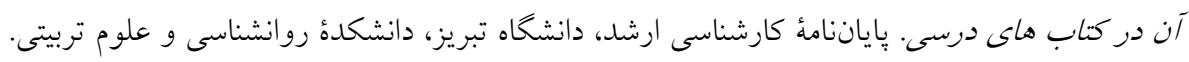

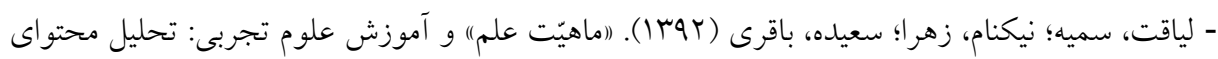
كتاب درسى علوم تجربى بايه سوم راهنمايى. فصلنامة مطالعات برنامة درسى /يران، سال هشتم، شماره 19-117:ص صو:19

- سلطانى، اصغر؛ شريف، مصطفى؛ ركنى زاده، رسول (IM Ir). بررسى وضعيت موجود و مطلوب برنامء درسى آموزش علوم مبتنى بر مؤلفههاى ماهيت علم از ديدكاه دانشجويان (مورد :دانشخاههاى اصفهان و 
ماهيت علم : مطالعه موردى نخرش دانشجويان ...

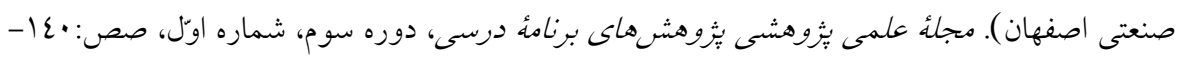

- افلاطونى، على (111). تأثير نابرابرى /قتصادى، اجتماعى و فرهنكى خانو/ده بر سطح سواد علمى دانش آموزان كروه راهنما ييى تحصيلى شهر قزوين. پاياننامه كارشناسى ارشد. دانشخاه تهران، دانشكده روانشناسى و علوم تربيتى.

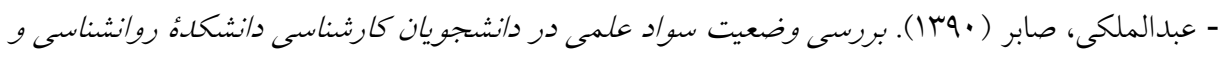
علوم تربيتى دانشكاءٔ علوم د/نشخاه تهران. بِاياننامه كارشناسى ارشد. دانشخاه تهران، دانشكده روانشناسى و علوم تربيتى.

- قانعى راد، سيد محمدامين و مرشدى، ابو الفضل ( •وس (1). بيمايش فهم عمومى از علم و فناورى: مطالعه

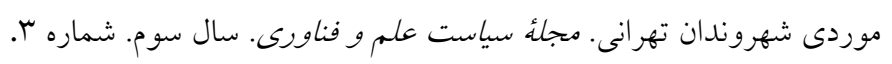

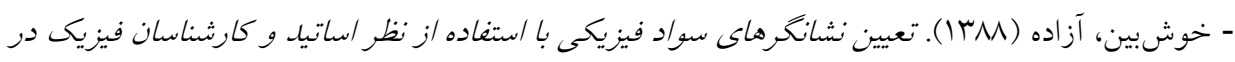
كشور /يران. ياياننامه كارشناسى ارشد، دانشگاه تربيت دبيرى شهيد رجايى، دانشكدهُ علوم بايه. - سلطانى، اصغر؛ شريف، مصطفى و ركنى زاده، رسول (1/1) (1). بررسى ديدكاه اعضاى هيئتعلمى در

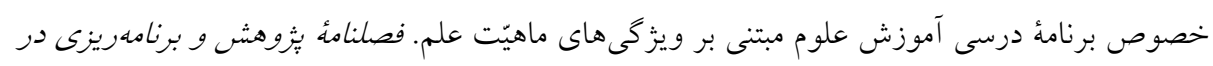
آموزش عالى، شماره 07، ص

- شيفر، ريجارد ال؛ مندن هال، ويليام و اوت لايمن (INYY) آماركيرى نمونهاى. ترجمه كريم منصور فر. تهران: انتشارات سمت (تاريخ انتشار به زباناصلى، (1991).

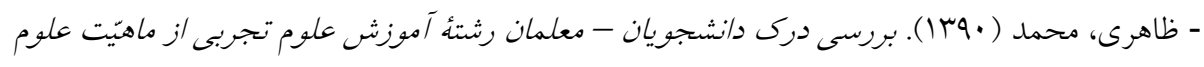
تجربى در مراكز تربيتمعلم /ستان تهر/ن. دانشخاه تهر ان. دانشكدة روانشناسى و علوم تربيتى دانشگاه تهران. بِاياننامة كارشناسى ارشد.

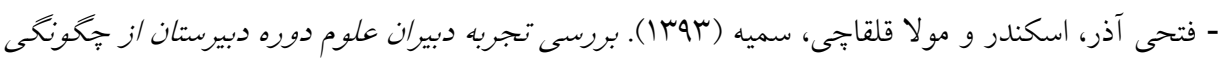
انعكاس ماهيّت علم در كتابهاى درسى :يك يزوهش كيفى و يديدارشناسى. همايش بين المللى فلسفه تعليم و تربيت در عمل.7 17 و ا مهرماه، دانشخاه خوارزمى.

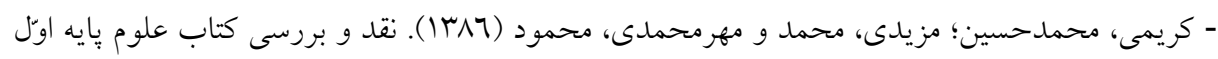
راهنمايى تحصيلى از منظر فلسفه علم. مجلئ علوم اجتماعى و انسانى دانشخاه شير/ز، دوره بيست و ششم، شماره سوم، بيnيى

- Abd-El-Khalick, F. \& Lederman, N. G. (2000). Improving science teachers' conceptions of nature of science: A critical review of the literature. International Journal of Science Education, 22(7), 665-701. 
- American Association for Advancement of Science. (1989). Science for all Americans.New York: Oxford University Press.

- American Association for Advancement of Science. (1993). Benchmarks for science literacy. New York: Oxford University Press

- Bell, R. L. \& Lederman, N. G. (2003). Understanding of the nature of science and decision making on science and technology based issues. Science Education, 87(3), 352-377.

- Bell, R. Blair, L. Crawford, B. \& Lederman, N. G. (2003). Just do it? The impact of a science apprenticeship program on high school students' understandings of the nature of science and scientific inquiry. Journal of Research in Science Teaching, 40, 487-509.

- Bybee,Rodger. McCrae,Barry. Laurie, Robert.(2006). PISA 2006: An Assessment of Scientific Literacy. JOURNAL OF RESEARCH IN SCIENCE TEACHING VOL. 46, NO. 8, PP. 865-883

- Dagher, Z.R. Brickhouse, N.W. Shipman, H. Letts, W.J. \& Sturt, C. (2004). How some college students represent their understandings of the nature of scientific theories. International Journal of Science Education, 26, 735-755.

- DeBoer.George E. $(20 \cdots)$. Scientifc Literacy: Another Look at Its Historical and Contemporary Meanings and Its Relationship to Science Education Reform. JOURNAL OF RESEARCH IN SCIENCE TEACHING. VOL. 37, NO. 6, PP. $582 \pm 601$

- Dogan, N. \& Abd-El-Khalick, F. (2008). Turkish grade 10 students' and science teachers' conceptions of nature of science: A national study. Journal of Research in Science Teaching, 45(10), 1083-1112.

- Driver, R. Leach, J. Millar, R. \& Scott, P. (1996). Young people's images of science. Buckingham, UK: Open University Press.

- Fishwild,Jon E.(2005). MODELING INSTRUCTION AND THE NATURE OF SCIENCE. A Thesis submitted in Partial Fulfillment of the requirements for The Master of Science Degree. THE UNIVERSITY OF WISCONSINWHITEWATER April 28, 2005 
ماهيت علم : مطالعه موردى نخرش دانشجويان ...

- Gallagher,J.J. (1991).Prospective and Practicing Sccondary School Science Teacher s Knowledge and Beliefs about the Philosophy of Science. Science Education 75, 121-133.

- Griffiths, A.K. \& Barman, C.R. (1995). High school students' views about the nature of science: Results from three countries. School Science \& Mathematics, 95, 248- 255.

- Halloun, I. \& Hestenes, D. (1998). Interpreting VASS dimensions and profiles for physics students. Science \& Education, 7, 553-577.

- Hazen, R. M.\& Trefil, J. (1991)Science matters.Achieving scientific Literacy.New York:Anchor Books Doubleday.

- Lederman, N. G \& Lederman, J. S. (2014). Is Nature of Science Going, Going, Going, Gone? Journal of science teacher education (2014) 25:235238 DOI 10.1007/s10972-014-9386-z.

- Holbrook, J. \& Rannikmae, M. (2009).The Meaning of Scientific Literacy. Tartu, Estonia: (International Journal of Environmental \& Science Education).

- Kang, S. Scharmann, L. C. \& Noh, T. (2005). Examining students' views on the nature of science: Results from Korean 6th, 8th, and 10th graders. Science Education, 89(2), 314-334.

- Murcia, K. (2006). Scientific literacy for Sustainability. Murdoch University, Perth, Western Australia. At http://wwwlib.murdoch.edu.au/adt/browse/view/adt-MU20070828.93112

- Xiao Qin, LAI. (2007).’The Initial Survey of Basic Scientific Literacy in Guangxi Middle School.Guangxi.china.Asia - Pacific Formon Science Learning and Teaching.volume8.issue2.articles10 (2007).

- Laugksch, C. R. (2000). Scientific literacy: A conceptual overview. Science Education. 84(1), $71-94$.

- Lederman, N. G. (1992). Students' and teachers' conceptions about the nature of science: A review of the research. Journal of Research in Science Teaching, 29, 331-359. 
دو فصلنامة نظريه و عمل در برنامة درسى، شماره 0، سال سوم، بهار و تابستان عهس|

- Lederman, N. G. Abd-El-Khalick, F. Bell, R. L. \& Schwartz, R. (2002). Views of nature of science questionnaire (VNOS): Toward valid and meaningful assessment of learners'

- Lederman, N. G. Wade, P. D. \& Bell, R. L. (1998). Assessing the nature of science: What is the nature of our assessments? Science and Education, 7, 595-615.

- Lederman, N.G. (1999). Teachers' understanding of the nature of science and classroom practice: Factors that facilitate or impede the relationship. Journal of Research in Science Teaching, 36, 916-929.

- Lederman, N.G. (2007). Nature of science: Past, present, and future. In S.K. Abell, \& N.G. Lederman, (Editors), Handbook of research in science education (pp 831-879). Mahwah, New Jersey: Lawrence Erlbaum Publishers.

- Liu, Xiufeng(2009) Beyond Science Literacy: Science and the Public: International Journal of Environmental \& Science Education. Vol. 4, No. 3, July 2009, 301-311.

- McComas, W. F. Clough, M. P. and Almazroa, H. (1998) The role and character of the nature of science in science education. In W. F. McComas (ed.) The nature of science education in science education: Rationales and strategies (pp. 3-39). Dordrecht, the Netherlands: Kluwer Academic Publishers.

- Moss, D.M. (2001). Examining student conceptions of the nature of science. International Journal of Science Education 23(8):771-790.

- National Research Council (1996). The national science education standards. Washington, DC: The National Academies Press.

- National Research Council. (2012). A Framework for K-12 Science Education: Practices, Crosscutting Concepts, and Core Ideas. Washington, DC.: Committee on a Conceptual Framework for New K-12 Science Education Standards. Board on Science Education, Division of Behavioral and Social Sciences and Education. 
ماهيت علم : مطالعه موردى نخرش دانشجويان ...

- National Research Council.(2000). Inquiry and the National Science

Education Standards: a guide for teaching and learning. National Academy Press. Washington, D.C. http://books.nap.edu/about/availpdf.phtml

- Norris, S.P., \& Phillips, L.M. (2003). How literacy in its fundamental sense is central to scientific lite-racy. Science Education, 87, 224-240

- OECD. (2006). Assessing scientific, reading and mathematical literacy: A framework for PISA 2006. Paris: OECD

- Ogunkola, B. J. (2013). Scientific Literacy: Conceptual Overview, Importance and Strategies for Improvement. Journal of Educational and Social Research, 3 (1), 9. doi: 10.5901

- Pelin,YALÇINOĞLU. Şengül S. ANAGÜN. (2012).Teaching Nature of Science by Explicit Approach to the Preservice Elementary Science Teachers. Elementary Education Online, 11(1), 118-136,

- Sadler, T.D. F.W. Chambers, and D. Zeidler.(2004). Student conceptualizations of the nature of science in response to a socioscientific issue. International Journal of Science Education 26(4):387-409

- Shamos, M. H. (1995). The myth of scientific literacy. New Brunswick, NJ: Rutgers University Press.

- Shanahan, M.C. \& Nieswandt, M. (2011). Science student role: Evidence of social structural norms specific to school science. Journal of Research in Science Teaching, 48(4), 367-395.

- Smith, C.L. (2000). Sixth-grade students' epistemologies of science: The impact of school science experiences on epistemological development. Cognition \& Instruction, 18, 349-422.

- Suzuri-Hernandez,Luis Jiro.(2010). Exploring school students' views of the nature of science. PhD Thesis. The university of York. Department of Education

- Tamir, P. (1994). Israeli students' conceptions of science and views about the scientific enterprise. Research in Science \& Technological Education, $12,99-116$. 
دو فصلنامةُ نظريه و عمل در برنامة درسى، شماره 0، سال سوم، بهار و تابستان ع وسا

- Zeidler, D.L. K.A. Walker, W.A. Ackett, and M.L. Simmons. 2002. Tangled up in views: Beliefs in the nature of science and responses to socioscientific dilemmas. Science Education 86(3):343-367

- Virginia Department of Education. (2010). Science standards of learning for Virginia public schools. Richmond: Virginia Board of Education.

- Finson, K. D. (2002). Drawing a scientist: What we do and do not know after fifty years of drawing. School Science \& Mathematics, 102(7):335-345

- Ramona E. Archer-Bradshaw,( 2014).Demystifying Scientific Literacy: Charting the Path for the 21st Century. Journal of Educational and Social Research MCSER Publishing, Rome-Italy. Vol. 4 No.3

- McComas.w.f.(2014). The Language of Science Education:An Expanded Glossary of Key Terms and Concepts in Science Teaching and Learning. Sense Publishers, AW Rotterdam, The Netherlands

- OECD. (2013). PISA 2015 draft science framework. http://www.oecd.org /callsfortenders/ Annex\%2 0IA_\%20PISA\%202015\%20Science\%20 Framework\%20.pdf

- Martin M.O \&Mullis I.V.S. \& Gonzalez E.J \& Chrostowski S.J(2004).TIMSS 2003 International Science Report. (IEA).TIMSS \& PIRLS International Study Center.USA.

- Osborne, J. Collins, S. Ratcliff e, M. Millar, R. \& Duschl, R. (2003). What "ideas-about- science" should be taught in school? A Delphi study of the expert community. Journal of Research in Science Teaching, 40, 692-720.

- Bell, R. (2009). Teaching the nature of science: Three critical questions. Best Practices in Science Education, 22, 1-6. 